\title{
Differences in Sexual Maturity and Related Characteristics Between Populations of Thorny Skate (Raja radiata) in the Northwest Atlantic
}

\author{
Wilfred Templeman \\ Science Branch, Department of Fisheries and Oceans \\ Northwest Atlantic Fisheries Centre, P. O. Box 5667 \\ St. John's, Newfoundland, Canada A1C 5X1
}

\begin{abstract}
Sexual maturity of the thorny skate (Raja radiata) occurs at relatively small sizes off northern Iceland and West Greenland, off Baffin Island and Labrador, on the Northeast Newfoundland Shelf and in the Gulf of St. Lawrence, and at considerably larger sizes on the Grand Bank and St. Pierre Bank. In areas with sexual maturity at a small length, the maximum fish lengths were typically small, and in areas with sexual maturity only at much greater lengths, the maximum lengths were considerably larger. The largest thorny skate was a 104-cm male from the southern Grand Bank. The lengths at sexual maturity and the maximum lengths for males were greater than those for females. One hermaphrodite was noted. There was a higher maximal number of rows of alar spines in areas with sexual maturity at a larger size. From the great differences between areas in length at sexual maturity, it is concluded that no large-scale migrations of thorny skate occurred between these areas.
\end{abstract}

\section{Introduction}

The thorny skate (Raja radiata) is common in the northern part of the North Atlantic. In the western North Atlantic, it occurs in depths of less than $40 \mathrm{~m}$ to more than $600 \mathrm{~m}$ along the coast of West Greenland from Disko Bay southward, and on the North American side, from Hudson Bay to Cape Cod. Occasional specimens are reported southward to South Carolina (Bigelow and Schroeder, 1953). The thorny skate is an abundant or the most abundant skate in the Canadian Atlantic area and in the Gulf of Maine (McEachran and Musick, 1975; Scott, 1982; Templeman, 1982, 1984a; Sinclair et al., 1984).

Among the many studies of elasmobranch characteristics related to sexual maturity, such as clasper and egg sizes, are those of Steven (1934), Templeman (1944, 1982), Phillipson (1955), Richards et al. (1963), Du Buit (1968), Kato (1971), Nakaya (1975), and Capapé (1977).

This paper reports on data related to sex and sexual maturity of thorny skates collected during 1947-72 from various parts of the Northwest Atlantic, and of a few specimens from northern Iceland. The size at sexual maturity is important for distinguishing between fish populations, for explaining some of the size and growth differences between populations, and for establishing a base against which future changes in size at sexual maturity due to fishing pressure or other causes may be measured. In the late immature condition, the positive allometric growth of eggs, shell glands and claspers, and the increase in the number of rows of alar spines, of thorny skate are good indicators of approaching maturity. All of these are useful in forming judgements regarding the stage of maturity and for comparing differences between populations. In this paper a population is a group of fish of the same species occupying an area at a particular time (Templeman, 1983); it does not imply that a separate stock exists in the area.

\section{Materials and Methods}

Thorny skate specimens were mainly collected from catches by research vessels of the Fisheries Research Board of Canada, Biological Station, St. John's, Newfoundland (now Science Branch, Fisheries and Oceans, St. John's), and were usually examined by the author at the Station or examined by the author at sea when he was present on cruises in all the northern areas from West Greenland (Div. 1ABCD) westward and southward to Div. 3KLM during 1959-65. Specimens collected for study at the Station were usually obtained during the last few days fishing and preserved in ice or frozen in ice. During long trips when the author was not present, some specimens were gutted and salted at sea and a few were preserved in $10 \%$ formalin for later examination. The egg volumes and shell-gland weights were from fresh material.

Sampling of catches in most areas was unbiased by length or sex, but occasionally for Div. 3NOPs, when it was apparent that larger fish were lacking in the samples already examined, otherwise unselected samples of the larger sizes of thorny skate, usually females in a combination of the maturing and mature sizes, were examined. Occasionally samples stratified in 5-10 $\mathrm{cm}$ length groups were requested for examination, but 


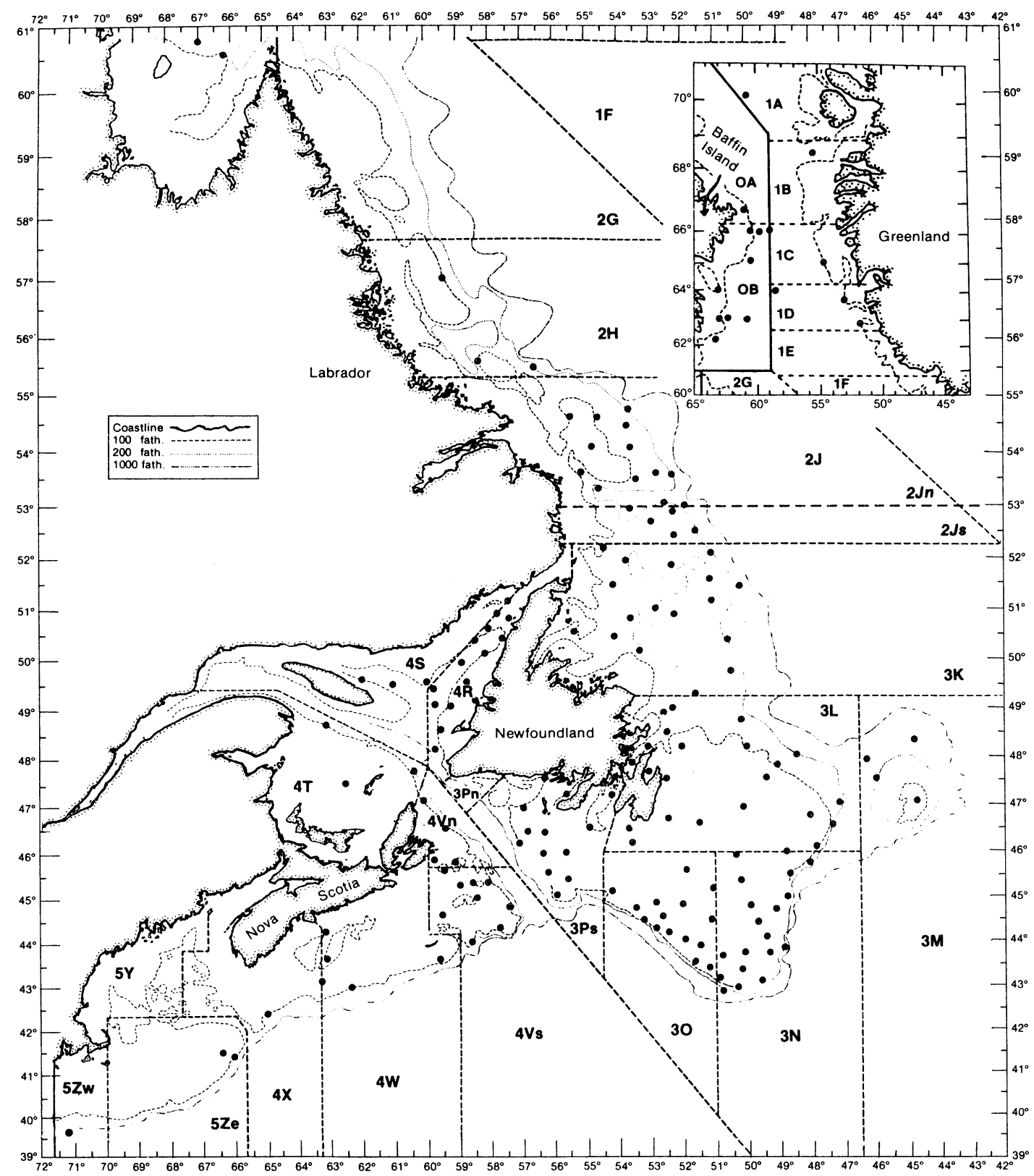

Fig. 1. Location of capture of thorny skate used in this paper, in relation to NAFO Divisions. (Subdiv. 2Jn and 2Js as used in this paper are also shown. The 43 thorny skate from northern Iceland, not indicated in this figure, were taken between $65^{\circ} 48^{\prime}$ and $66^{\circ} 31^{\prime} \mathrm{N}, 17^{\circ} 28^{\prime}$ and $20^{\circ} 49^{\prime} \mathrm{W}$ at $82-161 \mathrm{~m}$.)

none of the length categories were filled, indicating that all available thorny skate in these categories were collected.

The skate were taken mainly by bottom otter trawl but in some cases by bottom longline. For specimens preserved in salt or formalin, length adjustments for shrinkage were made using data gathered from skate measured fresh at sea and later from salt or $10 \%$ formalin after soaking for at least a day in water. Conversion factors to fresh length of 1.03 and 1.04 were applied to salt preserved and formalin-preserved speci- mens respectively. Frozen specimens were thawed in ice before examination.

NAFO Divisions and the locations and approximate depths of capture of the study material are shown in Fig. 1 and the quarter of the year, yearly periods and depth ranges of capture in Table 1. The Baffin Island, Labrador and Northeast Newfoundland Shelf (Div. $0 A-3 K)$ samples were all from deeper than 100 fath $(183 \mathrm{~m})$ and were mainly from 101 to 200 fath (185-366 $\mathrm{m})$. Shallow water fishing in these areas was often prevented by ice and fishing was directed towards cod and 
TABLE 1. Numbers of thorny skate observed by area, quarter of the year, yearly periods and depth range $(100$ fath $=183 \mathrm{~m})$.

\begin{tabular}{|c|c|c|c|c|c|c|c|c|c|}
\hline \multirow[b]{2}{*}{ Area } & \multicolumn{2}{|c|}{ Jan-Mar } & \multicolumn{2}{|c|}{ Apr-Jun } & \multicolumn{2}{|c|}{ Jul-Sep } & \multicolumn{2}{|c|}{ Oct-Dec } & \multirow{2}{*}{$\begin{array}{l}\text { Depth } \\
\text { (fath) }\end{array}$} \\
\hline & $1947-60$ & $1961-72$ & $1947-60$ & $1961-72$ & $1947-60$ & 1961-72 & 1947-60 & $1961-72$ & \\
\hline N. Iceland ${ }^{a}$ & - & - & - & - & - & 43 & - & - & $0-100$ \\
\hline \multirow{3}{*}{$1 \mathrm{ABCD}$} & - & - & - & - & - & 23 & - & - & $101-200$ \\
\hline & 1 & - & - & - & - & 15 & - & - & $201-300$ \\
\hline & - & - & - & - & - & 3 & - & - & $301-400$ \\
\hline \multirow[t]{3}{*}{$0 A-2 J n$} & - & 12 & 3 & 52 & 201 & 8 & - & - & $101-200$ \\
\hline & - & - & - & 41 & 34 & 6 & - & - & $201-300$ \\
\hline & - & - & - & 5 & 4 & - & - & - & $301-400$ \\
\hline \multirow[t]{3}{*}{$2 J s+3 K$} & - & - & - & 29 & 144 & 5 & 2 & 15 & $101-200$ \\
\hline & - & - & - & 19 & 3 & 6 & - & 2 & $201-300$ \\
\hline & - & - & - & 2 & - & 2 & 5 & - & $301-400$ \\
\hline \multirow[t]{4}{*}{$3 L$} & 1 & 1 & 76 & - & 141 & 10 & 50 & 17 & $0-100$ \\
\hline & 18 & 33 & 29 & 1 & 53 & - & 153 & - & $101-200$ \\
\hline & - & 7 & 1 & - & - & - & 1 & - & $201-300$ \\
\hline & - & - & - & - & - & - & - & 1 & $301-400$ \\
\hline \multirow[t]{4}{*}{$3 \mathrm{M}$} & - & - & - & - & 3 & - & - & - & $0-100$ \\
\hline & - & - & - & - & 5 & - & - & - & $101-200$ \\
\hline & - & - & 1 & - & - & - & 1 & - & $201-300$ \\
\hline & - & 4 & - & - & 2 & 2 & 1 & - & $301-410$ \\
\hline \multirow[t]{3}{*}{$3 N$} & - & 29 & 91 & - & 94 & - & 98 & 11 & $0-100$ \\
\hline & - & 6 & 10 & - & 33 & - & 23 & 15 & $101-200$ \\
\hline & - & - & 4 & - & - & - & - & - & $201-300$ \\
\hline \multirow[t]{4}{*}{30} & 120 & 6 & 107 & - & 8 & - & - & - & $0-100$ \\
\hline & 15 & 8 & 14 & - & 5 & - & - & - & $101-200$ \\
\hline & - & - & - & - & 3 & - & - & - & $201-300$ \\
\hline & - & - & 1 & - & - & 1 & - & - & $301-400$ \\
\hline \multirow[t]{2}{*}{ 3Ps } & 59 & - & 68 & 6 & 14 & - & 8 & - & 0-100 \\
\hline & 3 & - & 9 & 13 & 9 & - & 36 & - & $101-200$ \\
\hline \multirow[t]{2}{*}{$3 \mathrm{Pn}$} & 24 & 1 & - & - & - & - & - & - & 0-100 \\
\hline & - & 1 & - & - & - & - & - & - & $101-200$ \\
\hline \multirow[t]{2}{*}{ 4RST } & - & 25 & - & - & 253 & - & 2 & 1 & $0-100$ \\
\hline & - & 28 & - & - & 6 & - & 47 & 17 & $101-200$ \\
\hline \multirow[t]{4}{*}{$4 V W X$} & - & - & 2 & 14 & 1 & - & 24 & 14 & $0-100$ \\
\hline & - & 1 & - & 1 & - & - & 24 & 3 & $101-200$ \\
\hline & - & - & - & - & - & - & - & - & $201-300$ \\
\hline & - & - & - & - & - & - & 1 & - & $301-400$ \\
\hline \multirow[t]{3}{*}{$5 Z e$} & - & - & - & - & 63 & - & - & - & 0-100 \\
\hline & - & - & - & 1 & - & - & - & - & $101-200$ \\
\hline & - & - & - & 2 & - & - & - & - & $201-300$ \\
\hline Cape Cod & - & 2 & - & - & - & - & - & - & $201-300$ \\
\hline
\end{tabular}

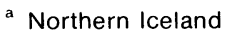

redfish on the slope. In more southern areas where the offshore banks are shallower than in the Canadian north, most of the samples came from less than 100 fath $(183 \mathrm{~m})$. In the north and from most other areas, most samples were taken in the April-September periods. Only the Grand Bank and the St. Pierre Bank areas had much sampling in January-March or October-December. By far the greater number of skate were from the earlier (1947-60) than from the later (1961-72) period. The samples of Table 1 were arranged by numbers of skate which were mature or immature, by area, depth, season, yearly period, length and sex. There were no real differences in lengths at which $50 \%$ were mature $\left(L_{50}\right)$ at $101-200$ fath $(185-366 \mathrm{~m})$ in the five areas with data available (Div. 3LNOPs, 4RST) compared with those at $0-100$ fath $(0-183 \mathrm{~m})$. At
201-300 fath (368-549 $\mathrm{m}$ ) with a small amount of data available for only two areas (Div. OA-2Jn and $2 \mathrm{Js}+3 \mathrm{~K}$ ), the $L_{50}$ 's could be several centimeters higher than at 101-200 fath, but the result is indefinite because of the very small numbers of fish at the greater depth (Table 1), i.e. only 8 mature males and 12 mature females in Div. OA-2Jn and 4 mature males and 5 mature females in Div. 2Js+3K. These small numbers from the greater depths have relatively little effect on the area totals compared, consequently data from all depths are combined for comparison between areas. Preliminary examination also indicated that differences in length at maturity could not be detected in the small amounts of yearly period and seasonal data available for each area. Thus only inter-area comparisons including all the data are presented here. 
Occasional skate were immature at lengths equal to or greater than the largest matures from the same area. This can be noted in Tables 2 and 3 , in Fig. 3 for Div. OA-2Jn, 2Js+3K, 30 samples, and in Fig. 4 and 5 for the Div. $2 \mathrm{Js}+3 \mathrm{~K}$ sample. These individuals increase the scatter and reduce the correlation of the particular parameter with fish length.

It was found that thorny skate from the southern part of Div. $2 \mathrm{~J}$ were more similar in maturity-related parameters to those from Div. $3 K$ than to those from the northern part of Div. 2J. Consequently, the northern and southern parts of Div. $2 \mathrm{~J}$ with the boundary line between them at $53^{\circ} \mathrm{N}$ were designated as Subdiv. 2Jn and $2 \mathrm{Js}$ respectively. This allows combination of the data from the Northeast Newfoundland Shelf in one group (2Js+3K), separate from those of the Labrador Shelf. Adjacent areas with small amounts of data which showed a similar maturity pattern were combined, but when large amounts of data were available, they were kept separate by NAFO Divisions for convenience in the figure presentations and to obtain comparisons between smaller areas. The resulting areas used for analysis are those given in Table 1.

Eighty-five percent of the sexually mature male skate were assessed as mature from the occurrence of milt in the vasa deferentia, $6 \%$ from milt in the epididymis, all with the enlargement and coiling of the vasa deferentia typical of mature males. The remainder were judged to be mature from a development and coiling of the vasa deferentia equivalent to the mature condition, together with such evidence as the hardening and size of the claspers and a number of rows of alar spines typical of mature males with abundant milt in the vasa deferentia.

Twenty-two percent of the mature females had developing or complete egg capsules. Assignment of the other females to the mature group was on the basis of the occurrence of large ovarian eggs of a size approximately similar to those in egg capsules, accompanied by the presence of an oviducal system comparable in size and development to that in females possessing egg capsules.

Large eggs of $2.0 \mathrm{~cm}$ and greater diameter were usually measured for volume by displacement of water in a graduated cylinder to the nearest tenth of a milliliter. In some cases the diameter of the egg was also measured to the nearest millimeter and the volume of a sphere of that diameter calculated, to compare with measured volume. It was found that calculated volumes of eggs of the larger diameters, especially in the vicinity

TABLE 2. Sample sizes of male thorny skate and percentages sexually mature at various total lengths from northern (N.) Iceland and from NAFO Divisions of the Northwest Atlantic collected during 1947-72.

\begin{tabular}{|c|c|c|c|c|c|c|c|c|c|c|c|c|c|c|c|c|c|c|c|c|c|c|c|c|c|}
\hline \multirow[b]{2}{*}{ Area } & \multicolumn{25}{|c|}{ Total length $(\mathrm{cm})$ (lengths are mid-points of $3-\mathrm{cm}$ length ranges) } \\
\hline & 32 & 35 & 38 & 41 & 44 & 47 & 50 & 53 & 56 & 59 & 62 & 65 & 68 & 71 & 74 & 77 & 80 & 83 & 86 & 89 & 92 & 95 & 98 & 101 & 104 \\
\hline \multicolumn{26}{|c|}{ Number of observations } \\
\hline N. Iceland & 1 & - & 2 & 2 & 1 & 2 & 4 & 7 & 3 & 1 & - & - & - & - & - & - & - & - & - & - & - & - & - & - & \\
\hline $1 \mathrm{ABCD}$ & - & - & 1 & 3 & - & 3 & 2 & - & 2 & - & 1 & - & - & - & - & - & - & - & - & - & - & - & - & - & - \\
\hline $0 A-2 J n$ & 15 & 11 & 9 & 15 & 22 & 20 & 23 & 30 & 18 & 6 & 1 & 1 & 1 & 1 & - & - & - & - & - & - & - & - & - & - & - \\
\hline $2 J s+3 K$ & 1 & 3 & 3 & 7 & 8 & 14 & 10 & 25 & 30 & 17 & 11 & 7 & 2 & 1 & - & 2 & - & - & - & - & - & - & - & - & - \\
\hline $3 L$ & 3 & 3 & 1 & - & 4 & 1 & 8 & 9 & 9 & 14 & 15 & 14 & 24 & 18 & 24 & 27 & 39 & 16 & 11 & 6 & 5 & 1 & - & - & - \\
\hline $3 N$ & - & 1 & - & - & 1 & - & - & 4 & 4 & 3 & 5 & 10 & 5 & 11 & 6 & 16 & 13 & 12 & 16 & 10 & 8 & 1 & 0 & 1 & - \\
\hline 30 & 1 & 1 & - & 2 & 2 & - & 3 & 1 & 1 & 2 & 2 & 4 & 1 & 4 & 1 & 6 & 5 & 8 & 8 & 14 & 14 & 5 & 2 & 2 & \\
\hline $3 \mathrm{Ps}$ & - & - & 2 & 2 & 3 & 1 & 2 & - & 2 & 1 & 4 & 3 & 3 & 3 & 2 & 8 & 1 & 6 & 5 & 7 & 2 & 2 & 1 & - & - \\
\hline 4RST & - & 4 & 4 & 8 & 7 & 10 & 18 & 22 & 21 & 30 & 32 & 15 & 9 & 1 & - & - & - & - & - & - & - & - & - & - & - \\
\hline $4 \mathrm{VWX}$ & - & 1 & - & 2 & 4 & 6 & - & 2 & 4 & 4 & - & 5 & 3 & 2 & 1 & 2 & 1 & 4 & - & - & 1 & 1 & 1 & - & - \\
\hline $5 Z e$ & 6 & 4 & 6 & 3 & 6 & - & 1 & 1 & - & 1 & 1 & 1 & - & - & - & - & - & - & - & - & - & - & - & - & - \\
\hline $3 M$ & - & 2 & 1 & - & - & - & - & 2 & - & 2 & 1 & 1 & - & - & - & - & - & - & - & - & - & - & - & - & - \\
\hline $3 P n$ & - & - & - & - & 1 & 3 & - & - & 1 & - & - & - & 1 & 1 & - & - & - & - & - & - & - & - & - & - & 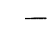 \\
\hline
\end{tabular}

Percentage sexually mature

\begin{tabular}{|c|c|c|c|c|c|c|c|c|c|c|c|c|c|c|c|c|c|c|c|c|c|c|c|c|c|}
\hline N. Iceland & 0 & - & 0 & 0 & 0 & 50 & 25 & 86 & 67 & 100 & - & - & - & - & - & - & - & - & - & - & - & - & - & - & - \\
\hline $1 \mathrm{ABCD}$ & - & - & 0 & 0 & - & 67 & 50 & - & 100 & - & 100 & - & - & - & - & - & - & - & - & - & - & - & - & - & - \\
\hline $0 A-2 J n$ & 0 & 0 & 0 & 20 & 50 & 50 & 83 & 93 & 90 & 83 & 100 & 100 & 100 & 100 & - & - & - & - & - & - & - & - & - & - & - \\
\hline $2 J s+3 K$ & 0 & 0 & 0 & 0 & 0 & 7 & 36 & 58 & 83 & 88 & 100 & 71 & 50 & 0 & - & 50 & - & - & - & - & - & - & - & - & - \\
\hline $3 \mathrm{~L}$ & 0 & 0 & 0 & - & 0 & 0 & 0 & 0 & 10 & 0 & 27 & 36 & 29 & 78 & 79 & 96 & 92 & 100 & 100 & 100 & 100 & 100 & - & - & - \\
\hline $3 N$ & - & 0 & - & - & 0 & - & - & 0 & 0 & 0 & 0 & 0 & 0 & 18 & 50 & 63 & 100 & 100 & 100 & 100 & 100 & 100 & - & 100 & - \\
\hline 30 & 0 & 0 & - & 0 & 0 & - & 0 & 0 & 0 & 0 & 0 & 0 & 0 & 0 & 0 & 50 & 40 & 75 & 88 & 86 & 100 & 80 & 100 & 100 & 100 \\
\hline $3 P s$ & - & - & 0 & 0 & 0 & 0 & 0 & - & 0 & 0 & 0 & 0 & 0 & 0 & 0 & 75 & 100 & 100 & 100 & 100 & 100 & 100 & 100 & - & - \\
\hline 4RST & - & 0 & 0 & 0 & 0 & 0 & 6 & 18 & 57 & 83 & 97 & 87 & 100 & 100 & - & - & - & - & - & - & - & - & - & - & - \\
\hline $4 V W X$ & - & 0 & - & 0 & 0 & 0 & - & 0 & 50 & 50 & - & 100 & 67 & 100 & 100 & 100 & 100 & 75 & - & - & 100 & 100 & 100 & - & - \\
\hline $5 Z e$ & 0 & 0 & 0 & 0 & 0 & - & 0 & 0 & - & 0 & 0 & 0 & - & - & - & - & - & - & - & - & - & - & - & - & - \\
\hline $3 \mathrm{M}$ & - & 0 & 0 & - & - & - & - & 50 & - & 100 & 0 & 0 & - & - & - & - & - & - & - & - & - & - & - & - & - \\
\hline $3 \mathrm{Pn}$ & - & - & - & - & 0 & 0 & - & - & 0 & - & - & - & 100 & 100 & - & - & - & - & - & - & - & - & - & - & - \\
\hline
\end{tabular}


TABLE 3. Sample sizes of female thorny skate and percentages sexually mature at various total lengths from northern (N.) Iceland and from NAFO Divisions of the Northwest Atlantic collected during 1947-72.

\begin{tabular}{|c|c|c|c|c|c|c|c|c|c|c|c|c|c|c|c|c|c|c|c|c|c|c|}
\hline \multirow[b]{2}{*}{ Area } & \multicolumn{22}{|c|}{ Total length $(\mathrm{cm})$ (lengths are mid-points of $3-\mathrm{cm}$ length ranges) } \\
\hline & 32 & 35 & 38 & 41 & 44 & 47 & 50 & 53 & 56 & 59 & 62 & 65 & 68 & 71 & 74 & 77 & 80 & 83 & 86 & 89 & 92 & 95 \\
\hline \multicolumn{23}{|c|}{ Number of observations } \\
\hline N. Iceland & 1 & - & - & 1 & - & 2 & 5 & 4 & 2 & - & - & - & - & - & - & - & - & - & - & - & - & - \\
\hline $1 \mathrm{ABCD}$ & - & - & 1 & - & 4 & 2 & 2 & 4 & 2 & 1 & - & - & - & - & - & - & - & - & - & - & - & - \\
\hline $0 \mathrm{~A}-2 \mathrm{Jn}$ & 12 & 15 & 13 & 13 & 21 & 13 & 10 & 9 & 4 & 2 & 1 & - & - & - & - & - & - & - & - & - & - & - \\
\hline $2 \mathrm{Js}+3 \mathrm{~K}$ & - & 2 & 3 & 9 & 3 & 10 & 13 & 13 & 14 & 4 & 5 & 3 & - & - & 1 & - & - & - & - & - & - & - \\
\hline $3 \mathrm{~L}$ & 3 & - & 2 & 4 & 7 & 2 & 7 & 9 & 17 & 16 & 25 & 35 & 46 & 44 & 47 & 34 & 20 & 4 & 4 & - & - & - \\
\hline $3 N$ & - & 4 & 3 & 2 & 1 & 2 & 5 & 1 & 2 & 4 & 11 & 14 & 34 & 57 & 53 & 44 & 18 & 7 & 5 & 2 & 1 & - \\
\hline 30 & 1 & 1 & - & 1 & - & 1 & 3 & 4 & 4 & 2 & 3 & 9 & 17 & 17 & 33 & 30 & 23 & 17 & 10 & 6 & 7 & 2 \\
\hline 3Ps & 2 & 2 & 1 & 1 & 2 & 2 & 1 & 1 & 3 & 5 & 4 & 7 & 18 & 24 & 17 & 21 & 17 & 5 & 5 & 1 & - & - \\
\hline 4RST & - & 1 & 3 & 4 & 10 & 7 & 17 & 34 & 39 & 45 & 21 & 9 & 3 & - & 1 & - & - & - & - & - & - & - \\
\hline $4 V W X$ & 1 & 2 & 1 & 5 & 2 & 2 & 1 & 1 & 7 & 3 & 3 & 3 & 1 & 1 & - & 1 & 1 & 1 & - & 1 & - & - \\
\hline $5 Z e$ & 2 & 6 & 1 & 5 & 3 & 2 & 1 & - & 2 & - & 2 & - & - & - & - & - & - & - & - & - & - & - \\
\hline $3 M$ & - & - & - & 1 & 1 & - & 4 & 1 & - & 1 & 2 & - & - & - & - & - & - & - & - & - & - & - \\
\hline $3 P n$ & - & - & 1 & 1 & 2 & 3 & - & 2 & 1 & 3 & 1 & 2 & 1 & - & 1 & - & - & - & - & - & - & - \\
\hline
\end{tabular}

Percentage sexually mature

\begin{tabular}{|c|c|c|c|c|c|c|c|c|c|c|c|c|c|c|c|c|c|c|c|c|c|c|}
\hline N. Iceland & 0 & - & - & 0 & - & 50 & 60 & 75 & 100 & - & - & - & - & - & - & - & - & - & - & - & - & - \\
\hline $1 \mathrm{ABCD}$ & - & - & 0 & - & 25 & 100 & 50 & 75 & 100 & 100 & - & - & - & - & - & - & - & - & - & - & - & - \\
\hline $0 A-2 J n$ & 0 & 0 & 0 & 15 & 48 & 92 & 80 & 78 & 75 & 0 & 0 & - & - & - & - & - & - & - & - & - & - & - \\
\hline $2 J s+3 K$ & - & 0 & 0 & 0 & 0 & 50 & 54 & 100 & 100 & 75 & 80 & 67 & - & - & 100 & - & - & - & - & - & - & - \\
\hline $3 \mathrm{~L}$ & 0 & - & 0 & 0 & 0 & 0 & 0 & 0 & 0 & 19 & 12 & 31 & 52 & 77 & 83 & 97 & 95 & 100 & 100 & - & - & - \\
\hline $3 \mathrm{~N}$ & - & 0 & 0 & 0 & 0 & 0 & 0 & 0 & 0 & 0 & 0 & 29 & 56 & 74 & 92 & 91 & 89 & 100 & 100 & 100 & 100 & - \\
\hline 30 & 0 & 0 & - & 0 & - & 0 & 0 & 0 & 0 & 0 & 0 & 11 & 12 & 29 & 67 & 73 & 87 & 71 & 90 & 100 & 86 & 50 \\
\hline 3Ps & 0 & 0 & 0 & 0 & 0 & 0 & 0 & 0 & 0 & 20 & 25 & 0 & 39 & 25 & 59 & 57 & 82 & 100 & 100 & 100 & - & - \\
\hline 4RST & - & 0 & 0 & 0 & 0 & 14 & 6 & 56 & 85 & 89 & 90 & 89 & 100 & - & 100 & - & - & - & - & - & - & - \\
\hline $4 \mathrm{VWX}$ & 0 & 0 & 0 & 0 & 0 & 0 & 0 & 0 & 0 & 0 & 34 & 34 & 100 & 100 & - & 0 & 100 & 0 & - & 100 & - & - \\
\hline $5 \mathrm{Ze}$ & 0 & 0 & 0 & 0 & 0 & 0 & 0 & - & 0 & - & 0 & - & - & - & - & - & - & - & - & - & - & - \\
\hline $3 \mathrm{M}$ & - & - & - & 0 & 0 & - & 25 & 0 & - & 100 & 0 & - & - & - & - & - & - & - & - & - & - & - \\
\hline $3 P n$ & - & - & 0 & 0 & 0 & 0 & - & 0 & 0 & 34 & 100 & 100 & 100 & - & 100 & - & - & - & - & - & - & - \\
\hline
\end{tabular}

of $3.0 \mathrm{~cm}$ and higher, were usually greater than the measured volumes as it was difficult to convert the large soft egg to a spherical shape which was attempted before measuring the diameter. Some eggs of $1.3-1.9 \mathrm{~cm}$ diameter $(1.2-3.6 \mathrm{ml})$ were measured for volume, and the volumes of the remainder of these and of smaller eggs were calculated from egg diameters assuming that the eggs were spherical. The differences in calculated and measured volumes $(\mathrm{ml})$ at these diameters were small.

Shell-gland weights were of the two empty shell glands weighed to the nearest gram. The rows of alar (spawning) spines (on the pectoral fins of maturing and mature male skate) were the number of medial to lateral longitudinal rows on one pectoral. As a more medial row is completed, the next more lateral row begins to form, and the spines which are soft at first gradually harden as the row grows to completion. When the new row began forming, the previous more medial row was counted as a complete row. The numbers of rows were usually recorded by whole and half rows but occasionally, especially at the beginning of the first and second rows, by quarters of a row. Clasper lengths were measured in millimeters plus or minus in relation to their extension or not beyond the posterior tips of the pelvic fins. The fish length measurements were of total length (cm) from the tip of the snout to the posterior end of the tail.

\section{Results}

\section{Variation in length at sexual maturity}

Sexual maturity occurred at the smallest lengths in Div. 0A-2Jn (Baffin Island - Labrador Shelf), with the $L_{5} 0$ occurring within the ranges of $44-50$ and $44-47 \mathrm{~cm}$ for males and females respectively (Tables 2 and 3 ). Similarly small lengths at $L_{50}$ occurred off northern Iceland and Div. 1ABCD (West Greenland). Much greater lengths at $L_{50}$, between about $68-83 \mathrm{~cm}$ for males and 65-74 cm for females, occurred in Div. 3LNOPs (Grand Bank, St. Pierre Bank and vicinity). Of the latter, $L_{5} 0$ in the males was lowest in Div. $3 L(68-71$ $\mathrm{cm})$ and highest in Div. $30(77-83 \mathrm{~cm})$, while $L_{5} 0$ in females was lowest in Div. $3 L N(65-68 \mathrm{~cm})$ and highest in Div. 3OPs $(71-74 \mathrm{~cm}$ ). L 50 's in Div. 2Js+3K (Northeast Newfoundland Shelf), $50-53 \mathrm{~cm}$ for males and 47-50 cm for females, and in Div. 4RST (Gulf of St. Lawrence), $53-56 \mathrm{~cm}$ for males and $50-53 \mathrm{~cm}$ for females, were only slightly higher than those in Div. $0 \mathrm{~A}-2 \mathrm{Jn}$. Data for the remaining areas are scarcer, but indicate that for Div. 3M (Flemish Cap) $L_{5} 0$ was likely to be low rather than high; that $L_{50}$ (female) in Div. 3Pn 
(western part of south coast of Newfoundland) was lower than in Div. 3Ps and higher than in Div. 4RST. $\mathrm{L}_{50}$ 's in Div. 4VWX (Scotian Shelf) were higher than in Div. 4RST and lower than those in Div. 3LNOPs. $L_{50}$ 's for Div. $5 Z$ e (Georges Bank) were probably high, as no matures were obtained in fish up to $62 \mathrm{~cm}$ female and 65 $\mathrm{cm}$ male.

Usually the $L_{50}$ for males was higher than that for females. Also, when sexual maturity was at a small length the maximum fish lengths attained were low and conversely with maturity at larger sizes. The smallest maximum fish lengths in present samples were consequently from the Baffin Island and Labrador shelves (Div. 0A-2Jn), northern Iceland and from West Greenland, and the largest were from the Grand Bank and St. Pierre Bank (Div. 3LNOPs) and the Scotian Shelf (Div. $4 \mathrm{VWX}$ ). The largest thorny skate observed in the samples were mature males of 103 and $104 \mathrm{~cm}$, and an immature female and a mature female with egg capsules, both $94 \mathrm{~cm}$ in total length, all from Div. 30 (southern Grand Bank).

Egg capsules were noted beginning at sizes of $40-45$ in areas with maturity at a small size and at 58-63 $\mathrm{cm}$ in areas with maturity at a large size (Table 4). In areas where sexual maturity began at small fish sizes, the percentages of mature females containing egg capsules were higher at smaller than at greater lengths whereas the reverse was evident for skate from areas where maturity began at greater fish size. These results

TABLE 4. Length composition of mature female thorny skate in relation to presence of egg capsules for (A) northern Iceland, Div. 1ABCD, Div. OA-2Jn, 2Js+3K, 3M, 4RST, and (B) Div. 3 LNOPs. (Fish with egg capsules from the earliest stage of development to completion were accepted as possessing egg capsules. Lengths are mid-points of $3-\mathrm{cm}$ length ranges.)

\begin{tabular}{|c|c|c|c|c|}
\hline \multirow{2}{*}{$\begin{array}{l}\text { Total } \\
\text { length } \\
(\mathrm{cm})\end{array}$} & \multicolumn{2}{|c|}{$\begin{array}{l}\text { (A) Areas with sexual maturity } \\
\text { beginning at small fish size }\end{array}$} & \multicolumn{2}{|c|}{$\begin{array}{l}\text { (B) Areas with sexual maturity } \\
\text { beginning at large fish size }\end{array}$} \\
\hline & $\begin{array}{l}\text { Mature } \\
\text { females }\end{array}$ & $\begin{array}{c}\% \text { with } \\
\text { egg capsules }\end{array}$ & $\begin{array}{l}\text { Mature } \\
\text { females }\end{array}$ & $\begin{array}{c}\% \text { with } \\
\text { egg capsules }\end{array}$ \\
\hline 41 & $2\}$ & & & \\
\hline 44 & $11\}$ & 31 & & \\
\hline 47 & 21 & 29 & & \\
\hline 50 & 20 & 15 & & \\
\hline 53 & 44 & 18 & & \\
\hline 56 & 52 & 19 & & \\
\hline 59 & 43 & 12 & $4\}$ & \\
\hline 62 & $23)$ & & $\left.{ }_{4}\right\}$ & 13 \\
\hline 65 & 10 & & 16 & 13 \\
\hline 68 & 3 & 16 & 51 & 14 \\
\hline 71 & 0 & & 86 & 27 \\
\hline 74 & 2) & & 120 & 23 \\
\hline 77 & & & 107 & 28 \\
\hline 80 & & & 69 & 26 \\
\hline 83 & & & 28 & 25 \\
\hline 86 & & & 23) & \\
\hline 89 & & & 9 & \\
\hline 92 & & & $7\}$ & 25 \\
\hline 95 & & & 1) & \\
\hline Total & 231 & 18 & 525 & 24 \\
\hline
\end{tabular}

are consistent with those based on more general criteria of maturity in females (Table 3 ), and confirm that these are largely correct. The higher percentage of fish with egg-capsules at the smallest sizes in the low-sizeat-maturity area could indicate an underestimation of mature fish at these sizes, and conversely, the lower percentage at the smallest sizes in the large-size-atmaturity area could indicate an overestimation. If this were so, the differences between areas would be even greater than those illustrated in Table 3.

\section{Volume of largest egg in ovaries}

Typically, in the ovaries of mature thorny skate, there is a pair of large eggs close to the size at which they are extruded from the ovaries and enter the oviducts and egg capsules, and several pairs of developed eggs declining in size below the largest.

The volume of the largest ovarian egg remained below $0.1 \mathrm{ml}$ until the approach of sexual maturity, when it increased rapidly toward the mature level of about 3-5 ml or greater (Fig. 2). Correlation coefficients of largest egg volume and fish length were low for all areas both for maturing and for mature fish. Egg volume was significantly correlated with length in mature fish from Div. 3LNO $(r=0.19-0.28, n=78-116$, $P \leqslant 0.05$ or 0.01 ) and was close to significance for Div. 4RST $(r=0.18, n=103)$. Correlation coefficients for other areas were similar $(r=0.16-0.31)$ but were not signficant due to the small numbers of observations (10-29). Similar correlation coefficients $(r=0.17-0.37)$ were obtained for maturing fish in the five areas Div. $3 \mathrm{LNOPs}$ and Div. 4RST, but again the numbers of observations were small (20-54) and these correlations were not significant. (Other areas were ignored because of the scarcity of observations.)

The weakness of the correlations of egg volume and mature skate length was unexpected because the weight of the egg capsule and the volume of the egg within the capsule were found by Templeman (1982) to be strongly correlated with fish length $(r=0.77$ and 0.84 respectively). Similarly the weight of the shell gland in which the capsule develops is strongly correlated with fish length in the mature skate of this paper. The volumes of the eggs in the egg-capsules (Templeman, 1982, fig. 4) ranged from 5 to $13 \mathrm{ml}$. Much larger numbers of the largest ovarian eggs (Fig. 2) were at 3-5 $\mathrm{ml}$ than in the egg capsules of Templeman (1982), but some ovarian eggs were equal to the largest from the egg capsules, and in Div. 3L extended $2 \mathrm{ml}$ or more beyond the largest egg of the egg capsules. This last observation may be a function of the much larger numbers examined for ovarian eggs than for eggs in egg capsules. Alternatively, there may have been some absorption of water by the ovarian eggs during the fish storage in ice. 


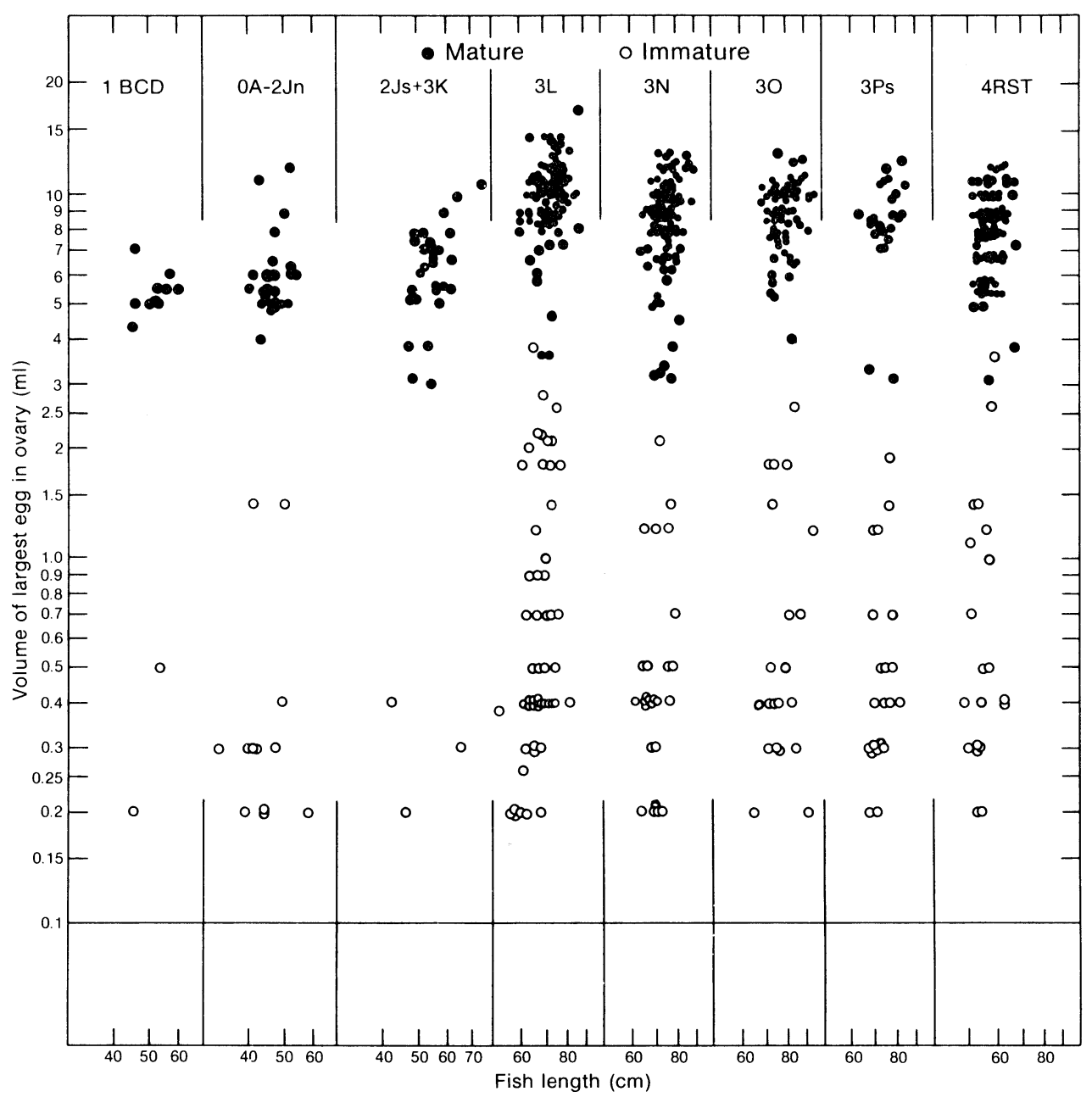

Fig. 2. Volume of largest egg in ovaries of female thorny skate from various NAFO Divisions in relation to fish total length. (Data as $\log _{10}$ values. Only egg volumes of $0.2 \mathrm{ml}$ and greater are plotted.)

While the eggs in the egg capsules represent the final size, the largest egg in the ovaries of a mature skate may range from an egg at maximum volume close to being liberated from the ovary, to the largest of the next pair after the extrusion of the largest pair from the ovary. Also, under the conditions of collection, some eggs broke. If the probability of breakage was directly related to egg size, the largest eggs would have had a lower probability of being measured. If both of what appeared to be the largest eggs were broken no measurement was taken and, when only one was broken, the smaller of the pair would be more likely to be whole and hence measured. It is also possible that, when there were breakages, an egg which was not one of the largest pair was mistakenly measured. Maturity occurs over a wide range of fish lengths and this would also contribute to the scatter of egg-volume in relation to fish length. All of these factors tended to reduce correlation of egg volume with fish length.

Much greater proportions of the largest eggs of mature females were at higher volume levels in Div.
3LNOPs where maturity began at a large size, than in Div. $1 B C D, 0 A-2 J n$ and $2 \mathrm{Js}+3 \mathrm{~K}$ where maturity occurred at a smaller fish length. Div. 4RST egg volumes were also somewhat higher. There were some low egg volumes in the vicinity of 3-4 $\mathrm{ml}$ in all areas.

The smallest mature skate, with the typical large ovarian eggs of this stage of maturity, begin between about $40-50 \mathrm{~cm}$ in Div. 1BCD, 0A-2Jn, 2Js+3K, 4RST, and between $60-70 \mathrm{~cm}$ in Div. 3LNOPs (Fig. 2). The smallest maturing (adolescent) females, i.e. those showing egg volumes beyond $0.2 \mathrm{ml}$, are close to the same fish length ranges, indicating that the attainment of mature size of eggs occurs rapidly once they enter the maturing stage.

\section{Shell-gland weight}

For most of the area, thorny skate were sampled over a small number of adjacent months (Table 1). It is consequently desirable to combine year-round data for comparison. One of the parameters which could vary seasonally is shell-gland weight. The data from Div. $3 \mathrm{~N}$ 


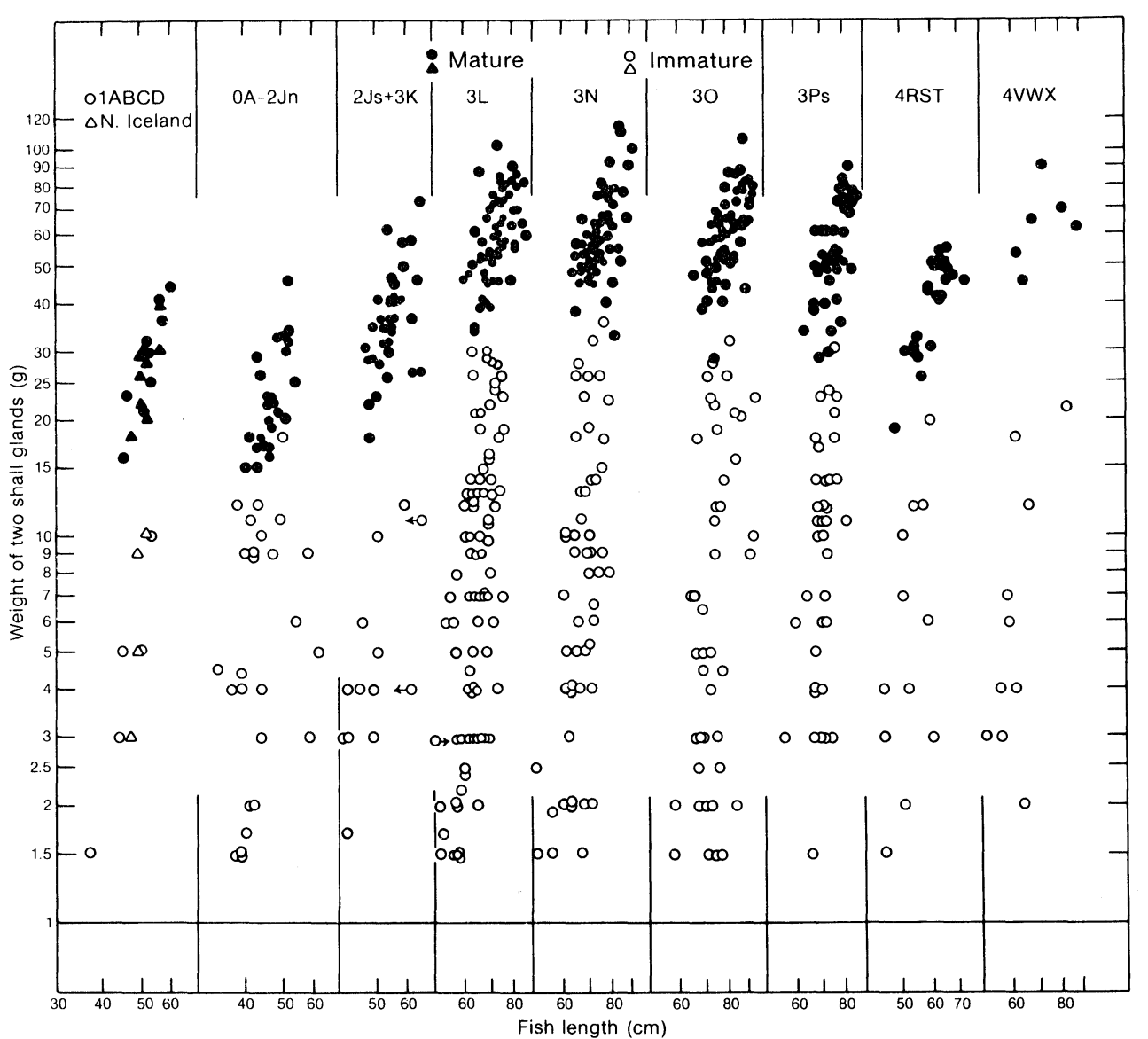

Fig. 3. Weight of two shell glands of adolescent and mature female thorny skate from various NAFO Divisions and from northern (N.) Iceland in relation to fish total length. (Data as $\log _{10}$ values. For Div. 3LNO, only three randomly selected points are shown at each length for mature fish. Only shell-gland weights of $1.5 \mathrm{~g}$ and greater are plotted.)

which were available over a wider range of months than usual were checked for weight of the two shell glands against fish length in mature females. These were available for 12 specimens in April-May, 42 in June-July, 39 in August, 21 in October-November and 51 in December. In view of the considerable variability and the small numbers of shell-gland weights at each length in a monthly or bimonthly period, no seasonality of shell-gland weight at fish-length was detected.

Shell-gland weights remained small at less than $1 \mathrm{~g}$ until with the approach of maturity they increased greatly to the mature condition when they weighed from 15 to $115 \mathrm{~g}$ (Fig. 3). Shell-gland weight is strongly correlated with fish length among fish in all areas $(r=$ $0.45-0.85, n=18-161, P \leqslant 0.01)$. Mean shell-gland weight was lower in areas of low size at maturity than in areas of high size at maturity. Mature skate had shell glands of $15-46 \mathrm{~g}$ in areas of low size at maturity (Div. $1 A B C D$, northern Iceland, Div. OA-2Jn), 18-74 $\mathrm{g}$ in areas with intermediate sizes at maturity (Div. $2 \mathrm{Js}+3 \mathrm{~K}$ and Div. 4RST) and 29-115 $\mathrm{g}$ in areas of high size at maturity (Div. 3LNOPS). In adolescent fish, there was also a tendency for shell-gland size to be correlated with fish length, with significant correlations occurring in 6 of 9 cases $(r=0.45-0.89, n=9-89, P \leqslant 0.01$ for 5 and $\leqslant 0.05$ for 1 ). In Div. OA-2Jn, 2Js $+3 \mathrm{~K}$ and $4 \mathrm{RST}$, correlations were not significant but numbers of observations were low ( $r=0.23-0.53, n=12-26)$.

The smallest mature skate with shell-glands of adult size occurred between $40-48 \mathrm{~cm}$ in northern lceland, Div. 1ABCD, 0A-2Jn, 2Js+3K, and 4RST, and between 60 and $66 \mathrm{~cm}$ in Div. 3LNOPs and Div. 4VWX.

\section{Alar spines, number of rows}

The number of rows of alar spines in mature male skate increased with increase in fish length (Fig. 4). In all nine areas from northern Iceland and West Greenland (Div. 1BCD) to the Scotian Shelf (Div. 4VWX), the correlation coefficients for the relationship of fish length and the number of rows of alar spines of adolescent plus mature male thorny skate were highly significant $(r=0.26-0.79, n=24-163, P \leqslant 0.01)$.

In areas where sexual maturity occurred at a small size and the adult skates were consequently small 


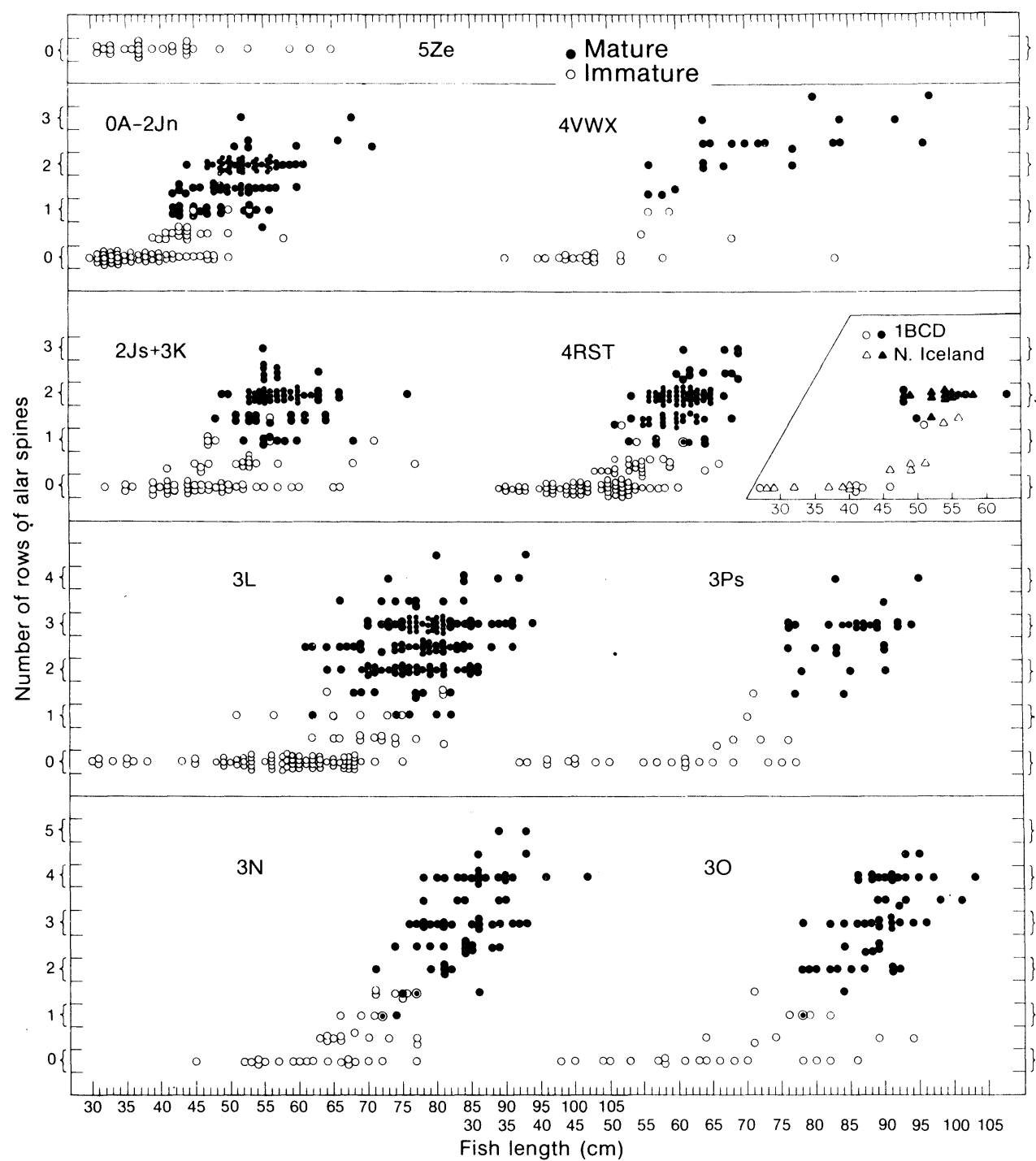

Fig. 4. Number of rows of alar spines of male thorny skate in various NAFO Divisions and from northern (N.) Iceland in relation to fish total length.

(northern Iceland, Div. 1BCD, Div. OA-2Jn and Div. $2 \mathrm{JS}+3 \mathrm{~K})$, there were few mature males with more than two rows of alar spines and none with more than three. In areas where sexual maturity began at a large size (Div. 3LNO and Subdiv. 3Ps), there were often many thorny skate with more than three rows of alar spines, some with four and one-half and occasionally (in Div. $3 \mathrm{~N}$ ) some with five rows (Fig. 4).

In all areas, all fish with two or more rows of alar spines were mature. The smallest skate with two or more rows of alar spines, were between 44 and $54 \mathrm{~cm}$ for northern Iceland, Div. 1BCD, 0A-2Jn, 2Js+3K, 4RST, and $71-78 \mathrm{~cm}$ for Div. 3NOPs. In the sample from Div. $5 Z \mathrm{Ze}$, all specimens were of $65 \mathrm{~cm}$ or less and possessed no alar spines (Fig. 4).

\section{Clasper length}

The relationship of clasper length to fish length was approximately sigmoid (Fig. 5). In small fish, clasper measurements were below zero and tended to show a slight negative slope with increasing fish length. In adolescent fish, there was usually a rapid increase in relative clasper length through a small range of fish lengths with a slower increase persisting after the attainment of maturity. For mature fish, clasper length was significantly correlated with fish length in all areas $(r=0.38-0.82, n=17-141, P \leqslant 0.01$ in 8 cases and $\leqslant 0.05$ in 1). For adolescent fish (described as immatures with a clasper length above zero) clasper length was correlated with fish length only in Div. $0 \mathrm{~A}-2 \mathrm{Jn}, 3 \mathrm{~L}$ and $3 \mathrm{~N}(\mathrm{r}=$ $0.42-0.54, n=27-49, P \leqslant 0.01$, or $\leqslant 0.05)$. The lack of 


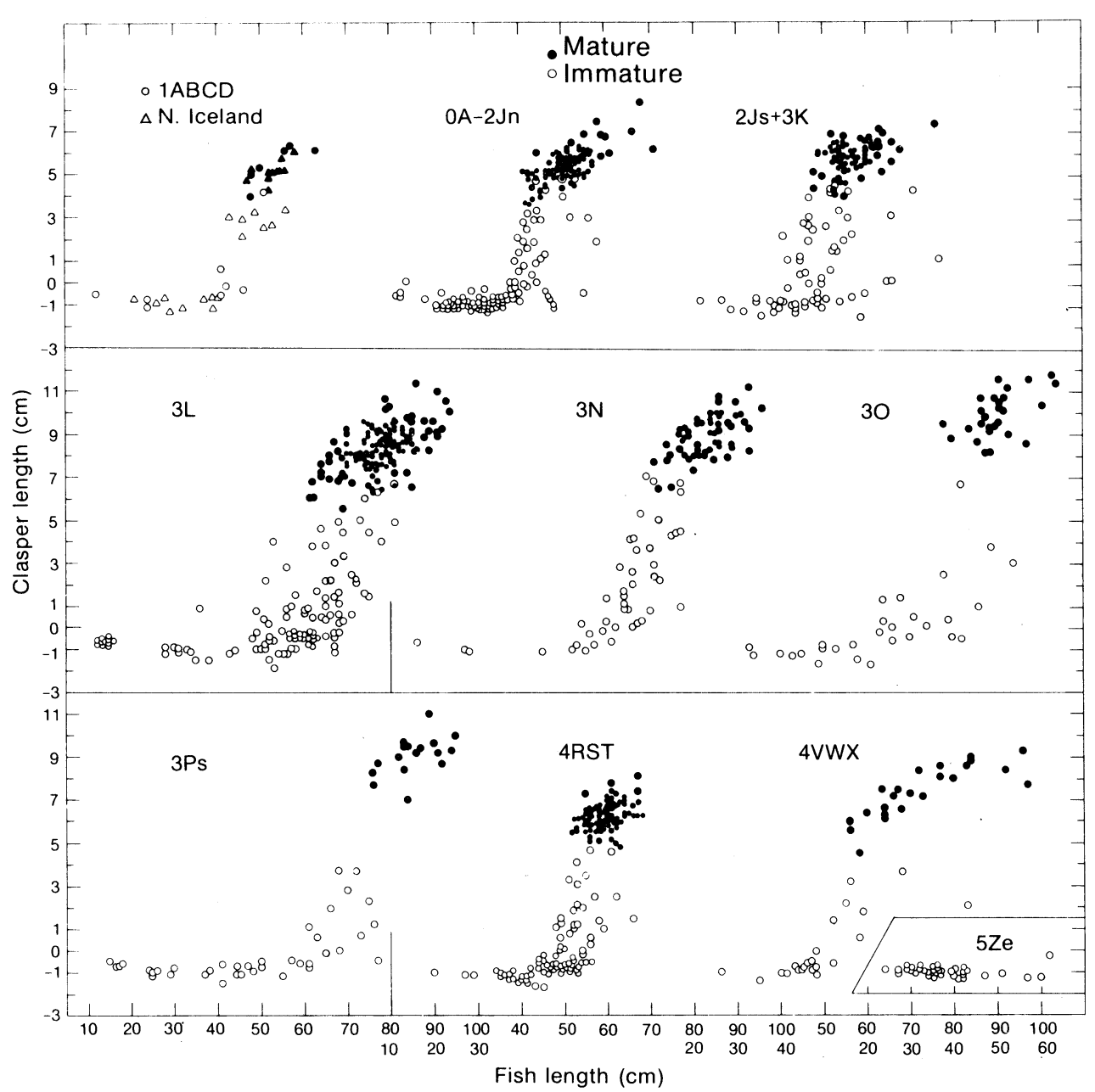

Fig. 5. Clasper length of male thorny skate from various NAFO Divisions and from northern (N.) Iceland in relation to fish total length.

significance in the remaining areas was due to the small numbers of observations in some cases $(n=7-31)$ or lack of specimens at the higher fish sizes i.e. to a narrow range of observations (Fig. 5), but could reflect a greater scatter in some populations (e.g. Div. 2Js+3K).

The median fish size at which the length of the claspers in the adolescent group rises to or above the zero line, i.e. where the tips of the claspers are level with the tips of the pelvic fins, marks the beginning of the rapid growth of claspers (Fig. 5). This length is approximately 44-47 cm for northern Iceland and Div. 1ABCD, 0A-2Jn, 2Js+3K; 51-52 cm for Div. 4RST, 4VWX; and 61-72 cm for Div. 3LNOPs. Clasper lengths of mature males were between $4-8 \mathrm{~cm}$ in northern Iceland, Div. $1 \mathrm{ABCD}$, Div. 0A-2Jn and $2 \mathrm{Js}+3 \mathrm{~K}$, between $5-9 \mathrm{~cm}$ in Div. 4RST and 4VWX, and between 6-12 cm in Div. 3LNOPS.

\section{Hermaphrodite}

One hermaphrodite was noted, an immature thorny skate $70 \mathrm{~cm}$ long from St. Pierre Bank $\left(46^{\circ} 24^{\prime} \mathrm{N}\right.$, $57^{\circ} 04^{\prime} \mathrm{W}, 42 \mathrm{~m}$ ) caught on 25 June 1951. This fish posessed shell glands weighing $1 \mathrm{~g}$ (for the pair) small oviducts and ovaries with small eggs. The claspers were showing some evidence of change toward maturity, extending $2 \mathrm{~mm}$ posterior to the tips of the pelvic fins. Immature testes were also present.

\section{Discussion and Conclusions}

Very few observations on sizes of sexually mature thorny skate are available in the literature but there are published data indicating possible differences in maximum length, which, based on the results of this paper, carry the implications of differences in length at sexual maturity. These records of maximum length can be compared with the extremes in maximum length and the corresponding smallest lengths at maturity and lengths at $50 \%$ mature of this paper which were as 
follows (in $\mathrm{cm}$ ):

\begin{tabular}{cccc}
\hline & & $\begin{array}{c}\text { Baffin I.-Labrador } \\
\text { (Div. OA-2Jn) }\end{array}$ & $\begin{array}{c}\text { Southern Grand } \\
\text { Bank (Div. 3O) }\end{array}$ \\
\hline Maximum fish length & males & $70-72$ & $103-104$ \\
& females & $61-63$ & 94 \\
Smallest mature fish & males & $40-42$ & $76-78$ \\
& females & $40-42$ & $61-63$ \\
Length at 50\% mature & males & $44-50$ & $77-83$ \\
& females & $44-47$ & $71-74$ \\
\hline
\end{tabular}

Other records of largest thorny skate from the North American area are $99 \mathrm{~cm}$ female and $113 \mathrm{~cm}$ male from off Canso, Nova Scotia (Cornish, 1907); $102 \mathrm{~cm}$ female from the Scotian Shelf off Halifax (Vladykov, 1936; and about $90 \mathrm{~cm}$ from Georges Bank (Bigelow and Schroeder, 1953). (In the author's records there is a 98-cm male thorny skate from west of the Gulf of Maine in $39^{\circ} 26^{\prime} \mathrm{N}, 72^{\circ} 03^{\prime} \mathrm{W}$, Fig. 1, Table 1.)

Some records of greatest lengths of thorny skate from other areas were: from the Barents Sea, $61 \mathrm{~cm}$ (Andriyashev, 1954), $65 \mathrm{~cm}$ from 8,002 specimens taken in 1980-81 (Nikiforova and Melyantsev, 1984), and $65 \mathrm{~cm}$ in 163 specimens (from the western Barents Sea and near Spitzbergen, Reinsch and Stein, 1985); about $60 \mathrm{~cm}$ from Norwegian waters (Bigelow and Schroeder, 1953); northeast of Shetland Islands (Tampen Bank $62^{\circ} \mathrm{N}, 2^{\circ} \mathrm{E}$ ) $64 \mathrm{~cm}$ from 276 thorny skate, minimum length of maturity for males $51 \mathrm{~cm}$ (Du Buit, 1970); North Sea, $45 \mathrm{~cm}$ (Bigelow and Schroeder, 1953), North Sea from 114 males largest disc width 35 $\mathrm{cm}$ (Phillipson, 1955) $=47 \mathrm{~cm}$ total length (using disc width $=75 \%$ total length, Templeman, 1987). From the change in slope of clasper length against disc width in Phillipson (1955, fig. 2), the smallest mature males from the North Sea are about $29 \mathrm{~cm}$ disc width $=39 \mathrm{~cm}$ total length. (The disc width of $73 \mathrm{~cm}=$ total length $97 \mathrm{~cm}$ with a 3-cm clasper length, in Phillipson's appendix table of disc width and clasper length of thcrny skate in the North Sea is evidently in error and disc widths apparently should be $23 \mathrm{~cm}$. There are some other apparent errors in this table, evidently misprints and interchanges between adjacent columns.) Clark (1926) described $R$. radiata from "numerous" North Sea and Icelandic specimens, total length $41-63 \mathrm{~cm}$, and stated that Icelandic specimens apparently reach a larger size than those from the North Sea. Other records of largest sizes recorded are $103 \mathrm{~cm}$ from the Faroes (Joensen and Tåning, 1970), $100 \mathrm{~cm}$ from Iceland (Saemundsson, 1927), $64 \mathrm{~cm}$ male and $65 \mathrm{~cm}$ female from West Greenland (Jensen, 1948).

It is apparent from these records of largest sizes, with the occasional record of mature sizes, that in the Northeast Atlantic the smallest sizes at sexual maturity are in the North Sea, increasing to the northeast toward the Barents Sea. Recorded sizes in the North Sea are smaller than, and in the Barents Sea are similar to, those in the regions of lowest maturity sizes of the Northwest Atlantic. Smallest sizes at maturity in the North Sea are similarly at least as small as those in the regions of the Northwest Atlantic with maturity at small sizes. West of the North Sea to Iceland and West Greenland, recorded sizes at maturity and maximum sizes generally are, as in the Barents Sea, low but somewhat higher than in the North Sea. However, at Iceland, where according to Saemundsson (1927) the thorny skate grows to a length of $100 \mathrm{~cm}$, it is possible that larger sizes at maturity and larger maximum sizes are found in the warmer waters at Southwest Iceland than the small sizes reported in this paper from northern Iceland. There may be differences in size at maturity from north to south in West Greenland as well, as this region was poorly sampled. It is likely that there is a cline of increasing size at sexual maturity from Labrador to the Gulf of St. Lawrence, and along the Scotian Shelf to the Gulf of Maine but sampling from the southern part of the region was poor. It is not possible with present data to reconcile the observation that the latitudinal direction of increase in size at maturity in the eastern Atlantic (North Sea to Barents Sea) is opposite to that in the western Atlantic.

The sexual-maturity pattern of the thorny skate in the eastern Canadian area, occurring at the smallest sizes off Baffin Island and Labrador, and at the largest sizes on the southwestern Grand Bank, is similar to that of the cod. Mature cod off Labrador are also small, whereas those of the southern Grand Bank grow to very large sizes (Fleming, 1960) as with thorny skate. The northern Gulf of St. Lawrence cod are relatively small at sexual maturity (Wiles and May, 1968), as are thorny skate from this area, but off West Greenland cod are relatively large at sexual maturity (Hansen, 1949) whereas the thorny skate mature at a relatively small size according to present data. In Atlantic wolffish (Anarhichas lupus), sexual maturity in females similarly begins at a relatively small size off Labrador and northeastern Newfoundland and at much larger sizes on the southern Grand Bank and on St. Pierre Bank (Templeman, 1986).

The rapid increases in egg volume and shell-gland weight during maturation can be used as an indication of the relative lengths at which female skate mature. Volumes of largest eggs and shell gland weights were lower in areas where maturity occurred at small fish lengths than in those with maturity at greater lengths (Table 3). Egg capsules (Templeman, 1982) were also small in the small, early maturing, thorny skate (corresponding to the smailer shell glands in which they were produced and to the smaller eggs developed for them) in comparison with those from areas with large size at maturity (and larger shell-glands and larger eggs developed for them.

The alar spines of male skates have been occasionally mentioned as a secondary sexual character indi- 
cating sexual maturity e.g. by Bigelow and Schroeder (1953) and Phillipson (1955) in $R$. radiata, Templeman (1965) in rare skates of the Newfoundland and adjacent areas and by Templeman (1973) in Bathyraja richardsoni. In this paper the smallest male thorny skate with two or more rows of alar spines, at which all were mature, occurred at small fish sizes in areas with small sizes at maturity and at corresponding larger sizes in areas where maturity began at larger sizes (Table 2). It appears most likely that the occurrence of more rows of alar spines in the larger skate from areas with maturity at large sizes, is a function of the necessity for more rows of these spawning spines in large than in small skate, to hold the female during the mating act.

Among elasmobranchs, similar changes in clasper length of males with fish length (or disc width), as described here for $R$. radiata, have (among others) been reported by Steven (1934) for $R$. clavata, Templeman (1944) for Squalus acanthias, Phillipson (1955) for $R$. radiata of the North Sea, Richards et al. (1963) for $R$. erinacea, Du Buit (1968) for R. clavata and R. batis, and Capapé (1977) for R. melitensis. Only occasionally in these researches were studies of sexual maturity carried out and related directly to the relative clasper lengths. Richards et al. (1963) reported that $R$. erinacea from Block Island Sound matured at a somewhat greater length than those from the adjacent Long Island Sound and that the rapid increase in relative clasper length in large immatures followed the same pattern. The general patterns of the relationship of clasper length to fish length for the many areas described for $R$. radiata in this paper were essentially similar to those above, with the exception that, at the smallest sizes, instead of a slow upward curve, there was at first a decline in clasper length relative to the total length. This is due to the method of measurement of clasper length used here (i.e. from posterior tip of pelvic fin). It is apparent also that clasper measurements, together with observations on the hardness of the claspers characterize fish approaching maturity and those mature. The median fish lengths at which the rapid adolescent growth begins in the claspers illustrate the same area differences as do the $50 \%$ maturity values, based largely on other criteria such as presence of milt and coiling of the vasa deferentia, shown in Table 2. The data of Fig. 5 illustrate again that, where sexual maturity begins at smalier lengths, the maximum fish sizes are smaller than those where sexual maturity occurs at greater lengths. The situation in Div. $4 \mathrm{VWX}$ is unclear. The few adolescent and the smallest mature skate indicate maturity at intermediate sizes, but the maximal length is similar to that of areas where maturity begins at larger sizes.

Decisions on the attainment of maturity in males depended largely on the presence of milt in the posterior vas deferens, to a much smaller degree on milt in the epididymis, together with considerable development and coiling of the vas deferens and hardening of the claspers. Bass et al. (1973) called sharks sexually mature when the claspers are fully grown with the clasper cartilage rigid from calcification. They state that semen is often present in sharks with immature claspers and should not be used as an index of maturity. They, however, use the presence of quantities of semen in the posterior parts of the vasa deferentia, the seminal vesicles, as an evidence of maturity. Fitz and Daiber (1963) found adult males of $R$. erinacea to carry sperm continuously from attainment of maturity until death.

In this paper, females with partially complete or complete egg capsules and females without capsules but with blood-suffused and distended oviducts were obviously mature and females with large ovarian eggs approximating in size those found in the egg capsules and possessing large shell glands of the sizes present in females with egg capsules were also mature or very close to first maturity. Richards et al. (1963) found some evidence of seasonality both in spawning and in gonad and shell-gland weight in mature female $R$. erinacea but the evidence for the latter was based on small numbers. Fitz and Daiber (1963) reported that, in southern New England waters, production of egg cases in $R$. erinacea occurs throughout the year. The greatest ovarian production was in the spring and the size and number of eggs were at a minimum in February-March. Du Buit (MS 1974) reported that egg-laying throughout the year is common for all species of Raja in European waters. Templeman (1982) observed incomplete and complete egg capsules for all seasons of the year in female $R$. radiata from the Northwest Atlantic. In the present investigations a very wide area with highly varying lengths at first maturity was covered, and in most divisions of the area the data were gathered over a small number of months, and, also, there were few and highly variable shell-gland weights at each length in the same month and area, thus seasonal effects could not be detected.

The results of tagging experiments for thorny skate (Templeman, 1984a) suggest that the species is fairly sedentary. Differences in size of egg capsules among areas (Templeman, 1982), and in the numbers of predorsal thorns and of rows of teeth (Templeman, 1984b), also suggest little mixing. The present data, showing large differences in size at sexual maturity among areas, are also consistent with this view. For males, both alar spines and clasper length relationships with fish length for Div. 4VWX indicate some possible mixing of low and high sizes of fish at maturity. However, it is likely that more than one thorny skate stock with different sizes at first maturity exist in these divisions rather than greater migration.

\section{Acknowledgements}

I am grateful to E. M. LeGrow, L. N. Cluett and A. G. Kelland, who worked with me in gathering much of the 
thorny skate data, and to the many biologists and technicians of the staff of the St. John's Station who helped to collect skate samples. I am also grateful to S. H. Lee, J. V. Arklie, J. R. Burt, and C. H. Riche for assistance in assembling the data and to H.W. Graham, of the Woods Hole Fisheries Laboratory, for a sample of thorny skate from Georges Bank.

\section{References}

ANDRIYASHEV, A.P. 1954. Fishes of the northern seas of the USSR. Dokl. Akad. Nauk SSSR, 53. (Transl. from Russian by Israel Prog. Sci. Transl., 1964, 617 p.).

BASS, A. J., J. D. D'AUBREY, and N. KISTNASAMY. 1973. Sharks of the east coast of southern Africa. I. The genus Carcharhinus (Carcharhinidae). South African Assoc. Mar. Biol. Res., Inves. Rep. Oceanogr. Res. Inst., No. 33 $168 \mathrm{p}$.

BIGELOW, H., and W. C. SCHROEDER. 1953. Fishes of the western North Atlantic. Sawfishes, guitarfishes, skates and rays. Mem. Sears Found. Mar. Res., 1(2): 514 p.

CAPAPÉ, C. 1977. Contribution à la biologie des Rajidae des côtes tunisiennes. VII. - Raja melitensis Clark, 1926: sexualité, reproduction, fécondité. Cah. Bio. Mar., 18: 177190.

CLARK, R. S. 1926. Rays and skates. A revision of the European species. Fish. Bd. Scot. Sci. Invest., 1: 66 p.

CORNISH, G. A. 1907. Notes on the fishes of Canso. Contrib. Can. Biol. Fish., N.S., 9: 81-90.

DU BUIT, M. H. 1968. Les raies (genre Raja) de la pêche francaise. Ecologie et morphométrie des principales espèces atlantiques. Univ. Rennes Trav. Fac. Sci. Sér. Océanogr. Biol., 1: 19-117.

1970. Répartition des Sélaciens démersaux au Nord de l'Ecosse. Univ. Rennes Trav. Fac. Sci. Sér. Océanogr. Biol., 3: 5-18.

MS 1974. Contribution à l'étude des populations des raies du Nord-est Atlantiques des Faeroe au Portugal. Thèse de Doctorat ès Sciences, Université de Paris VI, $171 \mathrm{p}$.

FITZ, E. S. Jr., and F. C. DAIBER. 1963. An introduction to the biology of Raja eglanteria Bosc 1802 and Raja erinacea Mitchill 1825 as they occur in Delaware Bay. Bull. Bingham Oceanogr. Coll., 18(3): 69-97.

FLEMING, A. M. 1960. Age, growth, and sexual maturity of cod (Gadus morhua L.) in the Newfoundland area, 1947-1950. J. Fish. Res. Board Can., 17: 775-809.

HANSEN, P. M. 1949. Studies on the biology of the cod in Greenland waters. ICES Rapp. Proc.-Verb., 123: 1-77.

JENSEN, A. S. 1948. Contributions to the ichthyofauna of Greenland 8-24. Spolia Zool. Mus. Hauniensis, Skrift. Univ. Zool. Mus. København, 9: 3-182.

JOENSEN, J. S., and A. V. TÅNING. 1970. Marine and freshwater fishes. Zool. Faroes, Copenhagen, $241 \mathrm{p}$.

KATO, F. 1971. Morphometric studies of the deep sea skate, Bathyraja smirnovi (Soldatov et Pavlenko). Bull. Jap. Reg. Fish. Res. Lab., 23: 69-81.

MCEACHRAN, J. D., and J. A. MUSICK. 1975. Distribution and relative abundance of seven species of skates (Pisces: Rajidae) which occur between Nova Scotia and Cape Hatteras. Fish. Bull. U.S., 73: 110-136.

NAKAYA, K. 1975. Taxonomy, comparative anatomy and phylogeny of Japanese catsharks, Scyliorhinidae. Mem Fac. Fish. Hokkaido Univ., 23(1): 1-94.

NIKIFOROVA, T. B., and R. V. MELYANTSEV. 1984. Distribution of thorny skate (Raja radiata) in the southern Barents Sea in 1980 and 1981. ICES Ann. Biol., 38: 202-203.

PHILLIPSON, J. 1955. Notes on morphological changes associated with sexual maturity in the male starry ray, Raja radiata Donovan. Proc. Univ. Durham Phil. Soc., 12(7): 63-72.

REINSCH, H. H., and M. STEIN. 1985. Fischereibiologiscke and ozeanographische Untersuchungen auf zwei Reisen mit dem Fischereiforschungsschiff "Anton Dohrn" 1980 and 1981 ins westliche Barentsmeer und nach Spitzbergen. Mitt. Inst. Seefisch. Hamburg, 35: 1-93.

RICHARDS, S. H., D. MERRIMAN, and L. H. CALHOUN. 1963. Studies on the marine resources of southern New England. IX. The biology of the Little skate, Raja erinacea Mitchill. Bull. Bingham Oceanogr. Coll., 18(3): 4-67.

SAEMUNDSSON, B. 1927. Synopsis of the fishes of Iceland. Rit V'́sind. Ísl., $66 \mathrm{p}$.

SCOTT, J. S. 1982. Depth, temperature, and salinity preferences of common fishes of the Scotian Shelf. J. Northw. Atl. Fish. Sci., 3: 29-39.

SINCLAIR, M., J. J. MAGUIRE, P. KOELLER, and J. S. SCOTT. 1984. Trophic dynamic models in light of current resource inventory data and stock assessment results. ICES Rapp. Proc.-Verb., 183: 269-284.

STEVEN, G. A. 1934. Observations on the growth of the claspers and cloaca in Raia clavata Linnaeus. J. Mar. Biol. Assoc., U.K., 19: 887-899.

TEMPLEMAN, W. 1944. The life-history of the spiny dogfish (Squalus acanthias) and the Vitamin A values of dogfish liver oil. Res. Bull. Dept. Natural Resources, Nfld., 15: $102 \mathrm{p}$.

1965. Rare skates of the Newfoundland and neighbouring areas. J. Fish. Res. Board Can., 22: 259-279.

1973. First records, description, distribution, and notes on the biology of Bathyraja richardsoni (Garrick) from the Northwest Atlantic. J. Fish. Res. Board Can ., 30: $1831-1840$.

1982. Development, occurrence, and characteristics of egg capsules of the thorny skate, Raja radiata, in the Northwest Atlantic. J. Northw. Atl. Fish. Sci., 3: 47-56.

1983. Stock discrimination in marine fishes. NAFO Sci. Coun. Studies, 6: 57-62.

1984a. Migrations of thorny skate, Raja radiata, tagged in the Newfoundland area. J. Northw. Atl. Fish. Sci., 5: 55-63.

1984b. Variations in numbers of predorsal median dorsal thorns and of rows of teeth in the thorny skate, Raja radiata, of the Northwest Atlantic. J. Northw. Atl. Fish. Sci., 5: 171-179.

1986. Some biological aspects of Atlantic wolffish (Anarhichas lupus) in the Northwest Atlantic. J. Northw. Atl. Fish. Sci., 7: 57-65.

1987. Length-weight relationships, morphometric characteristics and thorniness of thorny skate (Raja radiata) from the Northwest Atlantic. J. Northw. Atl. Fish. Sci., 7: this volume, p. 89-98.

VLADYKOV, V. D. 1936. Capsules d'oeufs de raies de l'Atlantique Canadien appartenant au genre Raja. Bull. Nat. Canadien, 63: 211-231.

WILES, M., and A. W. MAY. 1968. Biology and fishery of the West Newfoundland cod stock. ICNAF Res. Bull., 5: 5-43. 
